\title{
Transatlantica
}

Revue d'études américaines. American Studies Journal

Line Breaks in America: the Odds and Ends of Poetry

\section{Antoine Traisnel, Capture: American Pursuits and the Making of a New Animal Condition}

\section{Mark Niemeyer}

\section{(2) OpenEdition}

1 Journals

Electronic version

URL: https://journals.openedition.org/transatlantica/16670

DOI: 10.4000/transatlantica. 16670

ISSN: 1765-2766

Publisher

Association française d'Etudes Américaines (AFEA)

\section{Electronic reference}

Mark Niemeyer, "Antoine Traisnel, Capture: American Pursuits and the Making of a New Animal Condition", Transatlantica [Online], 1 | 2021, Online since 01 June 2021, connection on 05 February 2023. URL: http://journals.openedition.org/transatlantica/16670 ; DOI: https://doi.org/10.4000/transatlantica 16670

This text was automatically generated on 5 February 2023.

Creative Commons - Attribution-NonCommercial-NoDerivatives 4.0 International - CC BY-NC-ND 4.0 https://creativecommons.org/licenses/by-nc-nd/4.0/ 


\title{
Antoine Traisnel, Capture: American Pursuits and the Making of a New Animal Condition
}

\author{
Mark Niemeyer
}

\section{REFERENCES}

Antoine Traisnel, Capture: American Pursuits and the Making of a New Animal Condition Minneapolis: University of Minnesota Press, 2020, 354 pages, ISBN 978-1-5179-0964-2 (paperback), \$27.00

1 You can't judge a book by its cover. Or so they say. But the cover of Antoine Traisnel's Capture: American Pursuits and the Making of a New Animal Condition is striking and, one is tempted to say, captivating. And so is the book. The cover features colorful images of various birds-such as the ruby-throated hummingbird, the tufted coquette or the bufftailed sicklebill-taken from one of the most impressive plates in Ernst Haeckel's Kunstformen der Natur (Art Forms in Nature) and interlaced on a black background with the gold lettering of the book's main title. ${ }^{1}$ The birds depicted in Haeckel's original plate aren't exactly in a very natural or realistic setting, but on the cover of capture they are even further abstracted out of their environment, becoming highly aestheticized "captured" images. Traisnel's book focuses, in fact, on the change in America over the course of the nineteenth century from seeing animals as elusive individual beings that needed to be hunted down to seeing them as archetypal images to be captured and preserved. The study seeks to answer the following question: "During a century that saw the mass displacement of wildlife and the accelerated extinction of animals in the United States, how can we account for the emergence, and read the implications, of this new kind of hunt-one that claims no lives, only likenesses?" (2). Traisnel traces and theorizes this transformation, which he characterizes "as a shift from the hunt regime to the capture regime" (2), through an examination of various nineteenth-century American works of art and literature and 
experiments in stop-motion photography. Capture: American Pursuits and the Making of a New Animal Condition, thus, can best be described as a significant contribution to the growing field of animal studies, but it also offers, more broadly, innovative interpretations of the various cultural and scientific productions it explores.

The book's theoretical background is inspired, in part, by what Michel Foucault refers to as biopower, though here the figure coming increasingly under the control of that power is the animal, not man-and the stage is America, not Europe. The introduction lays out a theory of capture that the following chapters flesh out through specific case studies, which can be seen as representative rather than exhaustive. As Traisnel points out, "hunting narratives" often dominated depictions of the relationship between humans and animals in the American colonial and early national periods, and this view was still present, though undergoing transformation, in the early decades of the nineteenth century. Even a work as late as Moby-Dick; or, The Whale (1851), for example, shows this shift still incomplete since it clearly offers a story about the hunting of one particular (white) whale, but also, among other things, a search for the essence of whales more generally. Herman Melville's masterpiece is thus, according to Traisnel, simultaneously a story of hunting and a story of capture. As he explains, "Hunting supposes the copresence, however brief, uneven, and fortuitous, of the hunter and the hunted. Capture, however, disrupts this promise of contemporaneity, converting it to telos. As capture makes the subjection of that which is preyed upon appear predetermined, even preaccomplished, a form of nonpresence comes to saturate the animal's state of being. [...] Under capture, animals are assumed already at hand but fundamentally dislocated" (10). It could be noted that similar phenomena were occurring in the United States at the same time in the case, for example, of Native Americans, who, viewed as "vanishing," were being preserved (and aestheticized) for posterity by writers like James Fenimore Cooper and artists like George Catlin and, later, photographers like Edward S. Curtis or in the case of disappearing natural landscapes celebrated by writers like Washington Irving and, again, James Fenimore Cooper and artists of the Hudson River School like Thomas Cole and Asher Durand. As Antoine Traisnel notes, it was, in part, the reproducibility of the images of animals that allowed the technologies and discourses of capture to overtake and eventually replace those of hunting. Technological reproducibility, "strips its object of its naturalness, its originality, its singularity. Made into stock, the virtually limitless copy (the farmed or lab animal, the zoo specimen, the photographed beast) supersedes the nowunattainable (extinct or spatially marginalized) original" (14-15). As Traisnel explains at the end of his introduction, "Capture names the paradoxical regime of vision by which animals came to be seen as at once unknowable yet understood in advance-a frame by which we continue to encounter animals today" (29).

The first part of the book is entitled "Last Vestiges of the Hunt" and focuses on the waning days of the hunt paradigm through an examination of the illustrations (and writings) of John James Audubon (in chapter 1) and the Leatherstocking Tales of James Fenimore Cooper (in chapter 2). Audubon, Traisnel notes, saw himself as a huntereven had himself painted as a hunter with rifle in hand-and he created his now famous works of art reproduced in The Birds of America (which first appeared as a series between 1827 and 1838) from dead models, most of them killed by himself. At the same time, however, Audubon's goal was to create lifelike images, thus making him a precursor of the capture mentality. Traisnel offers an excellent example of this dualism 
in his perceptive analysis of the original watercolor and pastel version of Audubon's Golden Eagle, Aquila chrysaetos (1833), which portrays, he points out, "two versions of what appears to be the exact same eagle, simultaneously captured (on the hunter's shoulder) and free (as a bird). The fact that the eagle is at once dead and alive in the picture, like Schrödinger's cat in his box, implicitly correlates the killing of the empirical animal and its transformation into a representative specimen" (43). Tellingly, the image of the dead eagle (and the hunter) was removed from the engraving made from the original work of art and thus does not appear in the published (multiply reproduced) version. As this study makes clear, The Birds of America-an attempt, at least, to record the likenesses of every bird species in the United States-can be seen as a visual reflection of the shift from the logic of the hunt to the logic of capture.

4 Traisnel, who sees James Fenimore Cooper as another transitional figure, focuses in chapter 2 on the author's The Prairie; A Tale (1827). Though the work is the third of the Leatherstocking Tales to be published, it is the last of the five books from the point of view of the life of its central character, Natty Bumppo, whose death in the early nineteenth century is described in its last pages. As the American wilderness is tamed, the hunter, personified by Bumppo (by that time, in fact, transformed into a trapper), is left behind, a relic of the past. Traisnel makes an intriguing parallel between the dying world of the hunt and the romance genre in which Cooper was working, which, he suggests, was also disappearing. The observation is insightful, but the situation seems to be a bit more complex and bit more ambiguous than Traisnel suggests, in part because Cooper himself only retrospectively embraced the term "romance" as an appropriate label for the Leatherstocking Tales (or at least for the first three of them, written earlier than the last two) and, probably more importantly, because the romance genre was not so much dying at the time of the publication of The Prairie (Hawthorne, after all, whom I will come back to later, would still be keeping it alive three decades after the appearance of The Prairie) as it was, more fundamentally, a genre that has woven into it elements of nostalgia and pastness, which give it, among other things, an atmosphere of mourning. This quibble, however, does not invalidate Traisnel's essential point that Cooper's story and the romance genre are both intrinsically linked to the passing away of an older order. And, in The Prairie, the figure of the hunter is, appropriately enough, supplanted by that of the naturalist, Dr. Obed Bat, a seemingly minor character, at first apparently somewhat incongruous in the setting of the early nineteenth-century frontier, whose importance in the context of the movement towards the capture regime is clearly demonstrated through Traisnel's careful analysis.

5 The second part, "New Genres of Capture," highlights various ways in which capture came to dominate American thinking about animals over the course, approximately, of the second half of the nineteenth century. Chapter 3, "The Fugitive Animal," focuses on milieu, on "what happens to animals when we move (and move them) from the wilderness to the city" (92) through an examination of Edgar Allan Poe's "The Murders in the Rue Morgue" (1841). If C. Auguste Dupin, the detective in Poe's story, is a sort of hunter, he is no Natty Bumppo because in the city capture models of surveillance and control dominate. Indeed, what happens in an urban environment, as Walter Benjamin suggests, is that "people disappear as animals" (95), and the detective hunts down any remaining traces of animality, which become criminalized. Indeed, as Traisnel points out in an endnote, since the orangutan who commits the double murder in the story is finally caught and sold to the Jardin des Plantes in Paris, it "ends up behind bars" (256). 
Furthermore, as the century advances, animality often becomes racialized. In "The Murders in the Rue Morgue," before it is sold to the zoo, the orangutan "was first captured on the island of Borneo by a French sailor who smuggled him into the country with the intention to sell him. The ape is introduced in Paris as a commodity-a trajectory that evokes the forcible displacement of African subjects and their conversion into chattel during the Middle Passage" (106). But the animal, according to the capture paradigm, has no place in the city. As Traisnel writes, "glimpsed from across an abyss of unknowability, the animal disappears just as it comes into being; he is presented as a purely negative being whose motivations cannot be fathomed, whose voice defies intelligibility, and whose actions occur on an absolutely incommensurable plane" (119). Indeed, in "The Murders in the Rue Morgue," the orangutan "is never physically present in the diegesis but exists only through retrospective narration of his owner, the sailor" (119). His place in the capture regime is always elsewhere.

In "Fabulous Taxonomy" (chapter 4), Traisnel analyzes Nathaniel Hawthorne's The Marble Faun: Or, The Romance of Monte Beni (1860), whose central character, Donatello, is a faunlike creature whose very essence brings the question of the relationship between humanity and animality to the fore. Traisnel suggests that Hawthorne is playing games with his reader in his refusal to make explicit whether Donatello is a faun (or part-faun) or not-but this ambiguity, which in Hawthorne can, indeed, be maddening at times, does not have to be read, as Traisnel suggests, as "an appeal to ignorance" (127). Indeed, to return briefly to the question of the romance, it isn't necessarily true (despite certain weaknesses in The Marble Faun) that the work suffers from the fact that the genre "at the time of Hawthorne's writing was already passé, out of step with its time" (127) because, as already suggested, the romance genre, at least in the United States, was conceived, even when new, as imbued with a certain pastness, which is not necessarily the same thing as being passé. More importantly and more interestingly, however, Traisnel sees the romance as "an allegory of taxonomic knowledge-as a critical examination of how the newly prominent epistemology of capture altered the view and knowledge of animals" (128). As he rightly points out, The Marble Faun "challenges the taxonomic presumption associated with Cuvier, whose name is a metonym for the rigid worldview that dominated biology and geology in Europe during the first half of the century and, later, the United States under the influence of Louis Agassiz" (129). But the situation is less cut-and-dried than it may at first seem since Cuvier's work was, from one point of view, infused with a certain Romantic devotion to wholeness in its conception of an all-encompassing system. Nonetheless, Cuvier's attempt at eliminating uncertainty is countered by Hawthorne's embracing of it, notably in the floating taxonomic identity of Donatello. The character's ambiguity, however, Traisnel convincingly speculates, may very well have left Hawthorne's readers-who had evolved with their times and implicitly, it appears, adopted the mentality of capture-uncomfortable and wanting to know the extent of Donatello's animality and, potentially, his criminality (since he does, like Poe's orangutan, commit murder). Hawthorne, however, refuses to accommodate them (or us) and evokes "the possibility, however faint and ephemeral, however inconceivable and unspeakable within the epistemological frame erected by Cuvier, of a knowledge that extends beyond-or rather between-the taxonomic confines of species determination. This interval, which is not timeless, makes possible Hawthorne's fabulous taxonomy" (152).

The study shifts to a different domain in the last chapter, "The Stock Image," which at first seems somewhat out of place since it leaves the world of art and literature for that 
of science with its focus on Eadweard Muybridge's late-nineteenth century experiments in stop-action photography, which were among the first steps in the development of cinema. But animals-and the human conception of them-are central in Muybridge's work since one of his primary interests was in the movement of animals and since his most famous work is his study of galloping horses, prompted, so the story goes, by a request from the politician, railroad mogul and racehorse owner and breeder Leland Stanford (founder of Stanford University), who wanted to settle a debate over whether or not horses lifted all four hooves off the ground at any time when running (they do). Muybridge's work contributed to the creation of what Traisnel refers to as "machine time" (159-160), another step in the standardization process that helped usher in the world of capture. Horses, of course, being bred for various purposes, are themselves already products of technological manipulation. But Muybridge's experiments helped place them in a carefully controlled and regulated frame of large-scale image production. Furthermore, as Traisnel perceptively points out, this image production is especially important in the strengthening of capture because it accelerates the detaching of the animal from any basis in reality. What capture gathers, he writes, ends up having "no reality prior to the act of capture" since the data collected "acquires its ontological dignity as data" (165). And because, unlike Audubon, Muybridge (like his French chronophotographer counterpart Étienne-Jules Marey, whom Traisnel also briefly discusses) was not really interested in the individuality of his subjects, his productions are purer examples of capture. The result of the shift to capture is that "with the advent of technologies of reproduction, what is reproducible is real, and the real is reproducible" (179).

While the rise over the course of the nineteenth century of the capture regime may seem to have forever doomed animals to the role of prisoners in a sort of virtual existence and robbed them of all individuality, Traisnel suggests that such is not necessarily the case. An understanding of what has happened can also provide, he claims, "the basis for an ethics of life in capture" (193). If humans recognize, as Jakob von Uexküll suggests they should, that every living being "is enclosed in a milieu fully meaningful only to it" (195), then perhaps they can change their "anthropomorphic epistemological fervor that fueled the rise of capture in the nineteenth century" and begin "looking at animals not as objects to be seen but instead as subjects that see" (195). Such a possibility may seem a bit overly optimistic in an ever-more populous, urban and technology-dominated world, which often seems increasingly animalunfriendly despite the efforts of various animal rights groups and researchers in animal studies like Traisnel, but it's better to be hopeful than resigned.

Capture: American Pursuits and the Making of a New Animal Condition is a deep, intelligent and well-written study, which began as a doctoral dissertation. Clearly, that original work of research was carefully and thoughtfully revised in order to transform it into a solid, well-argued book. The language, it should be noted, does at times become rather abstract and complex as Traisnel works to theorize the concept of capture and clarify his own position in relation to those of a large number of thinkers and theorists. Capture is also thoroughly documented. The notes, in fact, are almost half the length of the main body of the text. While some of them, of course, offer simple documentation or what might be labeled "suggestions for further reading," many of them allow Traisnel to pursue his discussions and analyses in different and interesting directions without interrupting the logical flow of his main arguments-and any reader who skips them would be missing a number of thought-provoking remarks. The book also 
includes an extensive bibliography and a useful and detailed index. Besides its attractive cover, Capture includes twenty-eight black-and-white illustrations and four color plates, which not only make the work more appealing, but help clarify some of the arguments. And finally, it should be pointed out (and applauded) that the publisher of Capture, the University of Minnesota, is a participant in TOME (Toward an Open Monograph Ecosystem), a collaborative project designed to address the changes (and difficulties) in scholarly publishing in the humanities and social sciences by restructuring costs and making academic monographs more widely available. Thus, while this reviewer has a preference for real books one can hold in one's hands (and scribble notes in), it is certainly good news that Capture is freely available in an open access edition-perhaps a fitting, if not somewhat ironic, distinction for such an excellent study of the rise of the captured, endlessly reproducible image of animals.

\section{NOTES}

1. Sandra Friesen deserves mention for her impressive cover design.

\section{AUTHORS}

\section{MARK NIEMEYER}

Université de Bourgogne 